\title{
Analytical investigation of archaeological pottery fragments excavated from Porunthal, Tamil Nadu, India
}

\section{(Investigação analítica de fragmentos arqueológicos de cerâmica escavados em Porunthal, Tamil Nadu, Índia)}

\author{
G. Raja Annamalai ${ }^{1 *}$, R. Ravisankar ${ }^{2}$, A. Chandrasekaran ${ }^{3}$ \\ ${ }^{\prime}$ Valliammai Women's College of Arts and Science, Department of Physics, Arakandanallur 605752, \\ Villupuram, Tamil Nadu, India \\ ${ }^{2}$ Government Arts College, Post Graduate and Research Department of Physics, Tiruvannamalai 606603, Tamil Nadu, India \\ ${ }^{3}$ SSN College of Engineering, Department of Physics, Kalavakkam, Chennai 603110, Tamil Nadu, India
}

\begin{abstract}
Within the framework of a technological study of pottery production of Porunthal, Dindigul district of Tamil Nadu, India, the chemical composition and mineralogy of the 7 potteries of different varieties from that archaeological site were studied using Fouriertransform infrared spectroscopy (FTIR), X-ray diffraction (XRD), thermogravimetric analysis-derivative thermogravimetry (TGADTG), and scanning electron microscopy coupled with energy dispersive spectrometer (SEM-EDS). The analytical data obtained from several analyses were used to determine the mineral transformations during firing, such as quartz, feldspar, and iron oxides (hematite and magnetite), firing temperature, and firing conditions. The results of all the techniques confirmed that all the samples were manufactured by the artisans locally with the same raw materials and also were fired at the same temperature.
\end{abstract}

Keywords: archaeological samples, Porunthal/India, FTIR, XRD, thermal analysis, SEM-EDS.

\section{Resumo}

\begin{abstract}
No âmbito de um estudo tecnológico da produção de cerâmica de Porunthal, distrito de Dindigul, em Tamil Nadu, Índia, a composição química e mineralogia de 7 cerâmicas de diferentes variedades deste sítio arqueológico foram estudadas usando espectroscopia no infravermelho por transformada de Fourier (FTIR), difração de raios X (DRX), análise termogravimétrica-termogravimetria derivada (TGA-DTG) e microscopia eletrônica de varredura acoplada com espectrômetro por dispersão de energia (MEV-EDS). Os dados analíticos obtidos de várias análises foram utilizados para determinar as transformações minerais durante a queima, como quartzo, feldspato e óxidos de ferro (hematita e magnetita), temperatura de queima e condições de queima. Os resultados de todas as técnicas confirmaram que todas as amostras foram fabricadas pelos artesãos localmente com as mesmas matérias-primas e também foram queimadas na mesma temperatura.
\end{abstract}

Palavras-chave: amostras arqueológicas, Porunthal/Índia, FTIR, DRX, análise térmica, MEV-EDS.

\section{INTRODUCTION}

Potteries is one of the artifacts which might be most frequently unearthed by means of the archaeologist. The pottery techniques are extremely important for archaeologists as a source of results about cultural groups and their distribution areas. Through fragments of pottery, one can identify intercultural links or movements of populations in certain geographical areas [1]. To avoid thermal damages and for greater exposure to heat, the cooking pottery vessels are in all likelihood to have rounded shapes and also have relatively thin walls of better heat conduction and reduction of the thermal gradient between the inner and outer surfaces. The analysis of ancient pottery fragments offers information

*ramalai79@gmail.com

Dhttps://orcid.org/0000-0002-6886-4556 to archaeologists both on the technology used to make pottery and on the materials used in antiquity to realize artworks. Many archaeological investigations depend on the compositional evaluation of ceramic paste as a powerful source of information allowed to support different kinds of hypotheses about specific archaeological findings [2].

The main mineral phases may be determined by several spectroscopic techniques such as Fourier-transform infrared spectroscopy (FTIR) and X-ray diffraction (XRD) and also the elemental analysis performed by energy-dispersive $\mathrm{X}$-ray spectrometry (EDS) of the samples. FTIR spectroscopic technique is a very helpful analytical method to determine the mineralogical composition of archaeological pottery samples [3-7]. XRD technique is specially applied in the analysis of pottery because the main mineral crystalline phases may be found [8]. Among the various analytical methods used within the archaeological research, thermal analyses (thermogravimetric analysis-derivative thermogravimetry, 
TGA-DTG) have a highly analytical and guiding relevance. The mass loss in different decomposition stages in thermal analyses can reveal the firing temperature of the samples [9, 10]. The microstructures of the ceramic bodies, as well as the elements present in the archaeological fragments, can be examined by scanning electron microscopy (SEM) and EDS spectroscopy, respectively, in order to probe manufacturing skills and choices [11, 12].

The investigations of archaeological pottery samples of Porunthal in the present study were performed using FTIR, XRD, thermal analysis (TGA-DTG), and SEM-EDS techniques. The main objectives of the present study were the investigations of the archaeological potteries collected from the recent excavations in Porunthal, Tamil Nadu, India, using a combination of these 4 analytical techniques to characterize the mineralogy and elemental composition of pottery and to determine the firing temperature, firing conditions, and preparatory of raw materials for making pottery. A deep examination of 7 pottery samples indicated they were a similar group, which was confirmed in the mineral analysis by various spectroscopic techniques that gave the same chemical composition in all the potteries.

\section{EXPERIMENTAL}

Samples: Porunthal (longitude 10³4'58" N, latitude $77^{\circ} 52^{\prime} 59^{\prime \prime}$ E) is located $12 \mathrm{~km}$ southwest of Palani and marked as an archaeological site in 2006. In the years 2009 and 2010, the excavation was carried out, and ancient pottery samples were collected by the Department of History, School of Social Sciences \& International Studies, Pondicherry University, Puducherry, India. The collected pottery samples of Porunthal belong to the $5^{\text {th }}$ century BC. Black-and-red ware, redware, and black polished ware with different sizes were collected in the site and shown in Fig.1. The samples were designated as PP1, PP2, PP3, PP4, PP5, PP6, and PP7. After cleaning the surfaces, the samples were ground into a fine powder using an agate mortar for further analysis.

Methods. FTIR technique: Fourier-transform infrared spectra of the pottery samples were recorded with a spectrometer (Bruker, Alpha FTIR; resolution of $5 \mathrm{~cm}^{-1}$ )

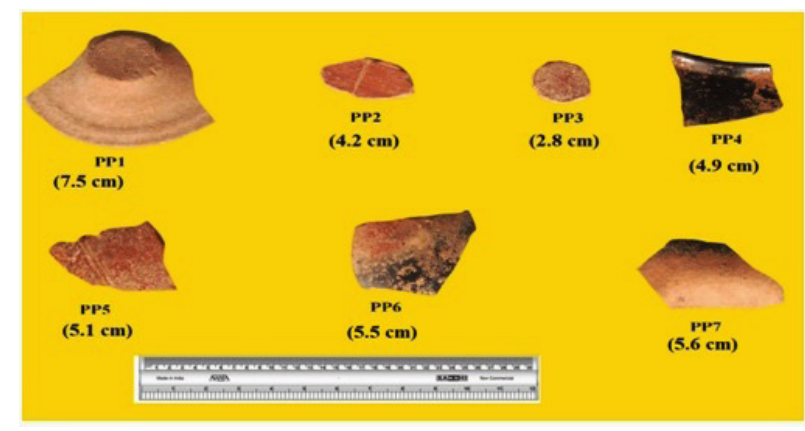

Figure 1: Investigated archaeological pottery fragments from Porunthal (India).

[Figura 1: Fragmentos de cerâmica arqueológica investigados de Porunthal (Índia).] using the $\mathrm{KBr}$ pellet technique in the wavenumber range of 4000 to $400 \mathrm{~cm}^{-1}$. The $\mathrm{KBr}$ pressed pellet was prepared by mixing the as-received powdered samples with $\mathrm{KBr}$ in the weight proportion of 1:20. XRD analysis: X-ray diffraction of the powdered pottery samples was carried out in a diffractometer (Siemens, D500 Advance) at room temperature using $\mathrm{CuK} \alpha$ radiation and a $\mathrm{NaI}(\mathrm{Tl})$ scintillation detector in the $2 \theta$ range from $10^{\circ}$ to $70^{\circ}$. The mineralogical composition of the studied samples was determined with the usual standard interpretation procedures of XRD. TGA-DTG analysis: as the thermogravimetric evaluation has received wide analytical acceptance in recent years for compositional analysis, the thermogravimetric analysis-derivative thermogravimetry (TGA-DTG) study was carried out for the samples in a thermal analyzer (TA Instr., SDT Q-600-V.8.0) by heating the samples between 30 to $1000{ }^{\circ} \mathrm{C}$ at $10{ }^{\circ} \mathrm{C} \cdot \mathrm{min}^{-1}$ in a high purity nitrogen flow. SEM-EDS analysis: the micrographs of the samples were recorded using a scanning electron microscope (SEM, FEI, Quanta; maximum magnification of 300000 times and a resolution of $3 \mathrm{~nm}$ ). The elemental analysis was carried out using an energy dispersive spectrometer (EDS, Oxford, INCA) coupled to the SEM. The samples coated with a thin layer of platinum were tested using SEM, typically with a magnification of $2000 \mathrm{X}$ for all the samples.

\section{RESULTS AND DISCUSSION}

FTIR analysis: the various mineralogical composition present in the selected pottery samples, such as black-andred ware (PP7), redware (PP1), and black polished ware (PP4) were studied by FTIR, and the spectra $\left(4000-400 \mathrm{~cm}^{-1}\right)$ are given in Fig. 2. The characteristic FTIR frequencies of the minerals possibly present in Porunthal potsherds are listed in Table I. The assignment was made on the basis of the characteristic IR wavenumbers of the minerals [2, 13-16]. The FTIR spectra revealed quartz $\left(798,778,694 \mathrm{~cm}^{-1}\right)$, hematite $\left(537,476 \mathrm{~cm}^{-1}\right)$, magnetite $\left(579 \mathrm{~cm}^{-1}\right)$, microcline $\left(1051,591 \mathrm{~cm}^{-1}\right)$, albite $\left(724 \mathrm{~cm}^{-1}\right)$, orthoclase $\left(728,462 \mathrm{~cm}^{-1}\right)$, organic residues $\left(2926,2853 \mathrm{~cm}^{-1}\right)$, and calcite $\left(713 \mathrm{~cm}^{-1}\right)$ bands. All the potteries included the main constituent quartz, as recognized with the aid of the characteristic band at 694 $\mathrm{cm}^{-1}$ and the doublet at 794 and $777 \mathrm{~cm}^{-1}$. It is made from a continuous framework of $\mathrm{SiO}_{4}$ silicon-oxygen tetrahedron, with each oxygen being shared between two tetrahedra, giving an overall formula $\mathrm{SiO}_{2}$. The doublet bands of quartz at 795-800 and $775-780 \mathrm{~cm}^{-1}$ may be assigned to symmetrical stretching modes, and those at $690-695 \mathrm{~cm}^{-1}$ may be due to the symmetrical bending mode [15]. The presence of a sharp band at $694 \mathrm{~cm}^{-1}$ indicates thin particles, and within the case of thick particles, this band is shifted to $689 \mathrm{~cm}^{-1}$ [17]. Since our shards showed this band at $694 \mathrm{~cm}^{-1}$, it was clear that this clay contained a quartz of thin particle size. The feldspar group of minerals (microcline, albite, and orthoclase) is a blanket term for a very large group of minerals that are abundant on Earth. Nearly $60 \%$ of the Earth's crust is comprised of feldspar; the feldspars are a gathering of 
minerals that have comparable attributes because of a comparable structure. The microcline was inferred due to the presence of peaks at 1051 and $591 \mathrm{~cm}^{-1}$. The absorption band at $724 \mathrm{~cm}^{-1}$ indicated in the samples the presence of the mineral albite. The mineral orthoclase was identified by the peaks at 728 and $462 \mathrm{~cm}^{-1}$ in the Porunthal samples. The very weak absorption bands at 2920-2925 and 2850-2855 $\mathrm{cm}^{-1}$ indicated the existence of organic carbon in the spectra of all the samples. These bands were due to $\mathrm{C}-\mathrm{H}$ absorption of contaminants present in the pottery samples, probably originated from organic residues. The amount of the organic contribution was higher in the red part in comparison with the black decoration part [18].

Hematite is the mineral form of iron (III) oxide $\left(\mathrm{Fe}_{2} \mathrm{O}_{3}\right)$, one among numerous iron oxides. Magnetite is a ferrimagnetic mineral with chemical formula $\mathrm{Fe}_{3} \mathrm{O}_{4}$ and a member of the spinel group. The amount of magnetite and hematite comes from the firing atmosphere used during the manufacturing of artifacts, whether reducing or oxidizing. The relative amount of hematite and magnetite

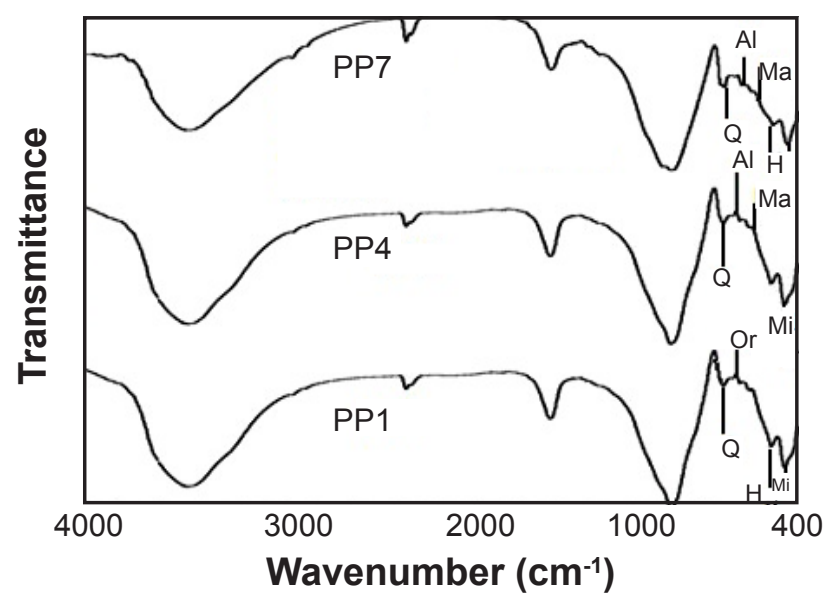

Figure 2: FTIR spectra of selected pottery samples of Porunthal. Q: quartz; Mi: microcline; Or: orthoclase; Al: albite; H: hematite; Ma: magnetite.

[Figura 2: Espectros de FTIR de amostras de cerâmica selecionadas de Porunthal. Q: quartzo; Mi: microclina; Or: ortoclásio; Al: albita; H: hematita; Ma: magnetita.] is responsible for the color of the potteries; the red color of the potteries is because of the presence of hematite, and black and gray colors are due to the higher amount of magnetite [19]. The variant in the amount of these iron oxides gives important information concerning the nature of the environment in which the potteries were fabricated. The properly-resolved and distinct peaks at 540 and $580 \mathrm{~cm}^{-1}$ in the spectra of the as-received samples revealed the presence of iron oxide minerals inclusive of hematite and magnetite, which additionally confirmed the firing temperature and firing atmosphere [20]. The presence of hematite indicates that the firing of the pottery was carried out in an oxidizing atmosphere during production [21], whereas the presence of a magnetite band can be indicative of a reducing atmosphere [22]. The prominent peak at $580 \mathrm{~cm}^{-1}$ in the samples PP4 and PP6 revealed that they were fired under the reducing atmosphere. The presence of the band at $540 \mathrm{~cm}^{-1}$ in PP1, PP2, PP3, PP5, and PP7 indicated that the samples were fired under the oxidizing atmosphere. The color indication is very important because some sherds can have red color on the surfaces (inner and outer) but black in the core (cross/ broken section: the fresh broken section). According to [23], if the fresh broken section is black, the firing atmosphere was reducing, and if the broken section is red, the firing atmosphere was the oxidizing atmosphere. Our samples PP1, PP2, PP3, PP5, and PP7 having red core indicated that the samples were fired under the oxidizing atmosphere, and PP4 and PP6 having black core indicated that the samples were fired under reducing atmosphere.

According to Ramasamy and Kamalakannan [24], the IR absorption band at $915 \mathrm{~cm}^{-1}$ because of $\mathrm{Al}(\mathrm{OH})$ vibrations in the octahedral sheet structure begins to disappear at 500 ${ }^{\circ} \mathrm{C}$ and completely disappears at $650{ }^{\circ} \mathrm{C}$. The shreds in the present study did not have any band at $915 \mathrm{~cm}^{-1}$. So it is feasible to suppose that all the shreds were fired above 650 ${ }^{\circ} \mathrm{C}$. The presence of hematite and magnetite additionally showed that the samples were fired above $650{ }^{\circ} \mathrm{C}$ [15]. Raja Annamalai et al. [4] investigated the firing temperature of potteries from archaeological sites of Tamil Nadu state, India. The results showed that these potteries might have been fired above $650{ }^{\circ} \mathrm{C}$ [4]. The atmospheric conditions,

Table I - Characteristic infrared frequencies $\left(\mathrm{cm}^{-1}\right)$ for the minerals possibly present in Porunthal potsherds.

[Tabela I - Frequências características no infravermelho $\left(\mathrm{cm}^{-1}\right)$ para os minerais possivelmente presentes nos fragmentos de Porunthal.]

\begin{tabular}{ccccccccc}
\hline Sample & Quartz & Microcline & Orthoclase & Albite & Hematite & Magnetite & $\begin{array}{c}\text { Organic } \\
\text { residue }\end{array}$ & Calcite \\
\hline PP1 & $795,778,693$ & 1049,592 & 729,463 & 723 & 476,541 & - & 2929,2854 & 712 \\
PP2 & $794,780,696$ & 1051 & 731,465 & 722 & 538 & - & 2930,2852 & - \\
PP3 & $796,777,691$ & 1052,593 & 727 & - & 542,479 & - & 2922,2848 & 715 \\
PP4 & 794,781 & 1047 & 464 & 725 & - & 578 & 2849 & - \\
PP5 & $795,781,693$ & 592 & 729,466 & 724 & 539,477 & - & 2924,2850 & - \\
PP6 & $798,775,692$ & 1051 & 730 & 721 & 543 & 581 & 2924 & 713 \\
PP7 & 794,779 & 461 & - & 723 & 537 & 577 & 2856 & - \\
\hline
\end{tabular}


Table II - Firing atmosphere and temperature of Porunthal pottery samples according to FTIR analysis.

[Tabela II - Atmosfera e temperatura de queima das amostras de cerâmica de Porunthal de acordo com a análise FTIR.]

\begin{tabular}{ccccccc}
\hline Sample & Ware type & $\begin{array}{c}\text { Color of broken } \\
\text { section }\end{array}$ & $\begin{array}{c}\text { Color of inner } \\
\text { surface }\end{array}$ & $\begin{array}{c}\text { Color of outer } \\
\text { surface }\end{array}$ & Atmosphere & $\begin{array}{c}\text { Firing } \\
\text { temperature }\end{array}$ \\
\hline PP1 & Red & Red & Red & Red & Oxidizing & $>650^{\circ} \mathrm{C}$ \\
PP2 & Red & Red & Red & Red & Oxidizing & $>650^{\circ} \mathrm{C}$ \\
PP3 & Red & Red & Red & Red & Oxidizing & $>650^{\circ} \mathrm{C}$ \\
PP4 & Black & Black & Black & Black & Reducing & $>650^{\circ} \mathrm{C}$ \\
PP5 & Red & Red & Red & Red & Oxidizing & $>650^{\circ} \mathrm{C}$ \\
PP6 & Black-and-red & Black & Black & Red & Reducing & $>650^{\circ} \mathrm{C}$ \\
PP7 & Black-and-red & Red & Black & Red & Oxidizing & $>650^{\circ} \mathrm{C}$ \\
\hline
\end{tabular}

firing temperature, and type of firing techniques used to make pottery utilized by the artisans at the time of producing the pottery samples excavated from Porunthal are given in Table II, based on the results of Fourier-transform infrared analysis.

XRD analysis: the mineralogical phases of the 7 archaeological pottery samples were identified by XRD analysis comparing with JCPDS files [25]. Typical X-ray diffraction patterns of Porunthal samples (Fig. 3) clearly confirmed the presence of mineral phases quartz, albite, orthoclase, and iron oxides (magnetite and hematite). The minerals detected in each sample by recording the XRD pattern are summarized in Table III. XRD analysis determined that the potsherds were very abundant in quartz, also had the presence of feldspar minerals, and traces of firing minerals such as hematite and magnetite (iron oxide minerals) [26]. The peaks of the crystalline mineral quartz (silica) were high and narrow (especially at the interplanar distance $\mathrm{d}$ of 4.26 , $3.34,2.46,2.28$, and $1.82 \AA$ ), showing a high crystallinity. But feldspar phases showed a worse crystallinity. The absence of appreciable calcite peaks in the patterns recorded from Porunthal shards suggested the firing temperature of samples could be higher than $750^{\circ} \mathrm{C}$. As far as our samples are concerned, the relevant XRD patterns confirmed that the artifacts contained orthoclase and albite; as an end result, they were not fired at temperatures beyond $750{ }^{\circ} \mathrm{C}$ [27]. The firing atmosphere of the potsherds can be clearly classified by color analysis; however, the identification of peculiar

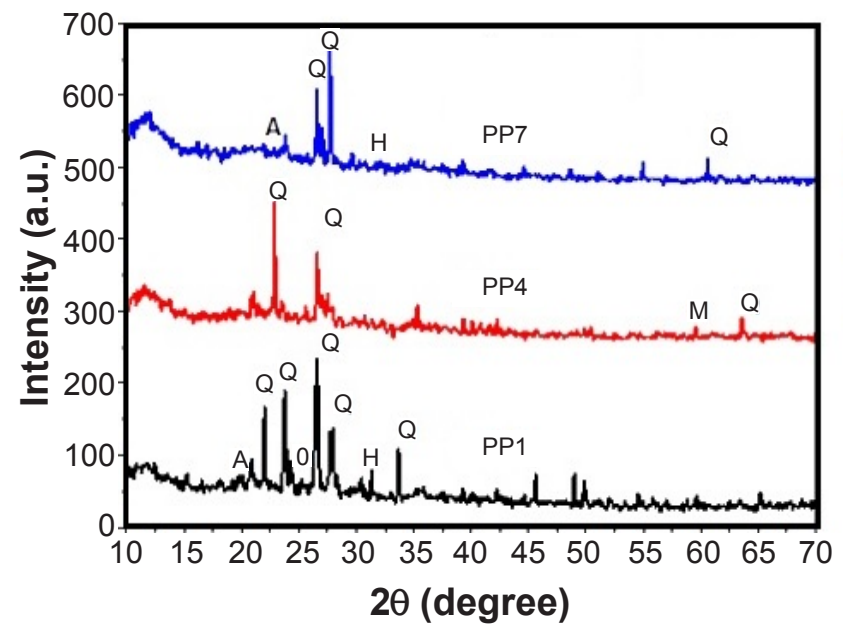

Figure 3: XRD patterns of the typical pottery samples of Porunthal. Q: quartz; O: orthoclase; A: albite; H: hematite; M: magnetite.

[Figura 3: Padrões de DRX das amostras típicas de cerâmica de Porunthal. Q: quartzo; O: ortoclásio; A: albita; H: hematita; M: magnetita.]

phases by way of infrared spectroscopy and XRD can also be fruitful: the presence of magnetite could corroborate reducing kiln conditions, whereas hematite would confirm oxidizing kiln conditions [28, 29].

Hematite, identified as a crystalline phase in our several samples, indicated an oxidizing kiln atmosphere. Actually, the mineral magnetite identified in the sample PP4 was

Table III - Mineralogical composition of pottery samples of Porunthal determined by XRD.

[Tabela III - Composição mineralógica das amostras de cerâmica de Porunthal determinadas por DRX.]

\begin{tabular}{cccccc}
\hline Sample & Quartz & Orthoclase & Albite & Hematite & Magnetite \\
\hline PP1 & Y & Y & N & Y & N \\
PP2 & Y & Y & N & Y & N \\
PP3 & Y & N & Y & Y & N \\
PP4 & Y & Y & N & N & Y \\
PP5 & Y & Y & N & Y & N \\
PP6 & Y & Y & Y & Y & N \\
PP7 & Y & N & Y & Y & Y \\
\hline
\end{tabular}

Y: present; $N$ : absent. 
indicative of a reducing atmosphere [29], but hematite was clearly identified in PP1, PP2, PP3, PP5, PP6, and PP7 samples; thus, all the relevant artworks except PP4 possibly were fired in oxidizing conditions. The coloring is indicative of iron oxides; brown or red color reveals the presence of hematite $\left(\mathrm{Fe}_{2} \mathrm{O}_{3}\right)$; the black or grey is an indication of magnetite $\left(\mathrm{Fe}_{3} \mathrm{O}_{4}\right)$ [14]. The presence of quartz, feldspar, magnetite, and hematite in all the pottery fragments was also evidenced by FTIR. XRD data analysis can also provide some insight into the manufacturing processes used in the production of these artifacts. The XRD measurement gave well-supporting information obtained from the FTIR spectroscopy.

Thermal analysis: the thermoanalytical TGA-DTG curves, on the possible firing temperature of different samples of Porunthal village, were studied. The characteristic thermal profile of the selected ancient pottery sample is represented in Fig. 4 and showed a total mass loss in different decomposition stages. The summarized results of the mass loss during heating at a different range of temperatures studied by thermogravimetric analysis of the archaeological samples are given in Table IV. The mass loss thermogram is only the simplest way to visualize the thermogravimetric

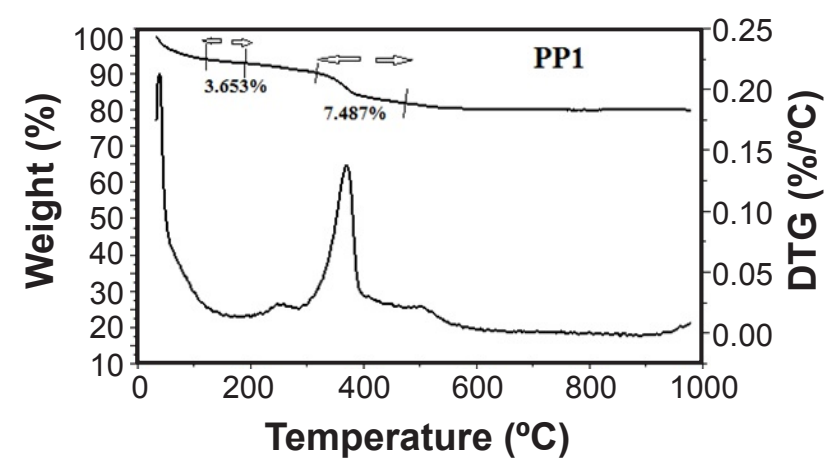

Figure 4: TGA-DTG curves of a selected pottery sample of Porunthal.

[Figura 4: Curvas de TGA-DTG de uma amostra de cerâmica selecionada de Porunthal.] outcomes of the evaluation of archaeological samples. Now in this way, several points have been faced that must be taken into consideration. Thermal effects can be measured in the thermogravimetric analysis, as they belong to the thermal changes during heating in ancient pottery samples, which takes place in 3 stages, such as dehydration, dehydroxylation, and decomposition of calcite $[10,30]$. In some cases, the results were corrupted due to impurities present in the samples. The derivative of mass loss (DTG) curve looks like those types of archaeological samples with peaks of: i) dehydration of moisture water present in the specimen with the maximum near $100-150^{\circ} \mathrm{C}$; ii) dehydroxylation of organic material with the maximum near $200-450{ }^{\circ} \mathrm{C}$ [31]; and iii) kaolinite decomposition with the maximum near 400$500{ }^{\circ} \mathrm{C}$ [32]. The organic compound might have been added intentionally as a binder in the manufacturing of pottery, or the raw material itself contained organic material [32]. The absence of dehydroxylation of the kaolinite peak indicated that all the potteries were fired above this temperature.

The weight reduction of the pottery in the thermogravimetric analysis (TGA) can also be defined in 3 steps based on: i) dehydration from room temperature to $100{ }^{\circ} \mathrm{C}$; ii) decomposition of hydroxyls from 400 to $500{ }^{\circ} \mathrm{C}$; and iii) decomposition of carbonates (calcite) from 700 to $800{ }^{\circ} \mathrm{C}[10]$. The mass loss on dehydration for the samples with variable water content (3-5\%) was measured. Careful measurement of mass loss on dehydroxylation is required for pure clays with very high weight loss (above 7-10\%). In many cases, the weight loss was so large, and the temperature of the dehydroxylation was so high that the process lasted too long in the last part of dehydroxylation. None of the samples confirmed weight loss due to the decomposition of calcite, which occurs from 700 to $800{ }^{\circ} \mathrm{C}$, indicating that calcite was absent in all the samples. The higher weight loss found in the samples was within 50 to $550^{\circ} \mathrm{C}$ due to dehydration and combustion of organic materials. The average total weight loss throughout the experiment was $19.9 \%$. Porunthal pottery samples possibly were fired in the temperature range of 700 to $800{ }^{\circ} \mathrm{C}$ during manufacturing. From this discussion, it is concluded that the firing temperature of samples was above

Table IV - TGA data of potsherds of Porunthal, India. [Tabela IV - Dados de TGA de fragmentos de Porunthal, Índia.]

\begin{tabular}{cccccc}
\hline Sample & \multicolumn{2}{c}{ Weight loss $(\%)$} & & Residual \\
& $\begin{array}{c}\text { Dehydration } \\
\left(30-200^{\circ} \mathrm{C}\right)\end{array}$ & $\begin{array}{c}\text { Decomposition of } \\
\text { hydroxyls }\left(400-650^{\circ} \mathrm{C}\right)\end{array}$ & $\begin{array}{c}\text { Decomposition of } \\
\text { calcite }\left(700-800{ }^{\circ} \mathrm{C}\right)\end{array}$ & Total & mass $(\%)$ \\
\hline PP1 & 4.15 & 8.27 & 0 & 17.53 & 82.47 \\
PP2 & 3.74 & 7.62 & 0 & 19.78 & 80.22 \\
PP3 & 4.84 & 9.67 & 0 & 18.66 & 81.34 \\
PP4 & 3.55 & 7.73 & 0 & 20.11 & 79.89 \\
PP5 & 2.65 & 9.24 & 0 & 21.07 & 78.93 \\
PP6 & 3.26 & 7.47 & 0 & 22.12 & 77.88 \\
PP7 & 4.77 & 8.82 & 0 & 20.02 & 79.98 \\
\hline
\end{tabular}


$650^{\circ} \mathrm{C}$, which is in good agreement with the results of FTIR and XRD analyses.

SEM-EDS analysis: the elemental composition ( $\mathrm{Si}$, $\mathrm{Al}, \mathrm{Fe}, \mathrm{Ca}$, etc.) of the two selected shreds PP1 and PP4 were characterized by recording energy dispersive X-ray spectra shown in Figs. 5a and 5b, respectively. The EDS measurements demonstrated that the samples PP1 and PP4 consisted mainly of $\mathrm{SiO}_{2}(62.48 \%), \mathrm{Al}_{2} \mathrm{O}_{3}(18.56 \%)$, $\mathrm{Na}_{2} \mathrm{O}(3.93 \%), \mathrm{MgO}(1.41 \%), \mathrm{CaO}(4.72 \%), \mathrm{K}_{2} \mathrm{O}(2.77 \%)$, and $\mathrm{Fe}(6.13 \%)$. The chemical composition and amount of inclusions vary with the provenance of the specimens. For the redware (PP1) and black ware (PP4) samples from Porunthal (Tamil Nadu, India), a high amount of quartz was observed, and only a small amount of feldspar $\left(\mathrm{Na}_{2} \mathrm{O}, \mathrm{MgO}\right.$, $\mathrm{Al}_{2} \mathrm{O}_{3}, \mathrm{CaO}$, and $\mathrm{K}_{2} \mathrm{O}$ ) inclusions was found. Even though the pottery samples contained a small amount of $\mathrm{Na}_{2} \mathrm{O}$, $\mathrm{MgO}, \mathrm{K}_{2} \mathrm{O}$, and $\mathrm{CaO}(<10 \mathrm{wt} \%)$, the amount of alkali oxides was systematically higher than that of the alkaline earth oxides. This is well-known and revealed that the alkalis were not only introduced as impurities from the siliceous raw materials but that an additional alkali source was used as nicely, probably potassium or sodium-rich plant ashes [33]. According to Maniatis and Tite [34], if the pottery shreds have less than $6 \%$ of $\mathrm{Ca}$, the clay used to make the historic pot is non-calcareous in nature. Based on this, the results of EDS indicated that the samples PP1 and PP4 were made of non-calcareous clay since the percentage of $\mathrm{Ca}$ found in PP1 was $3.29 \%$ and in PP4 was $4.72 \%$.

The internal morphology of the pottery samples PP1 and PP4 were evaluated using a scanning electron microscope. SEM micrograph in Fig. 6a shows the initial vitrification stage in the non-calcareous pottery fragment PP1. The improvement of vitrification also depends on the
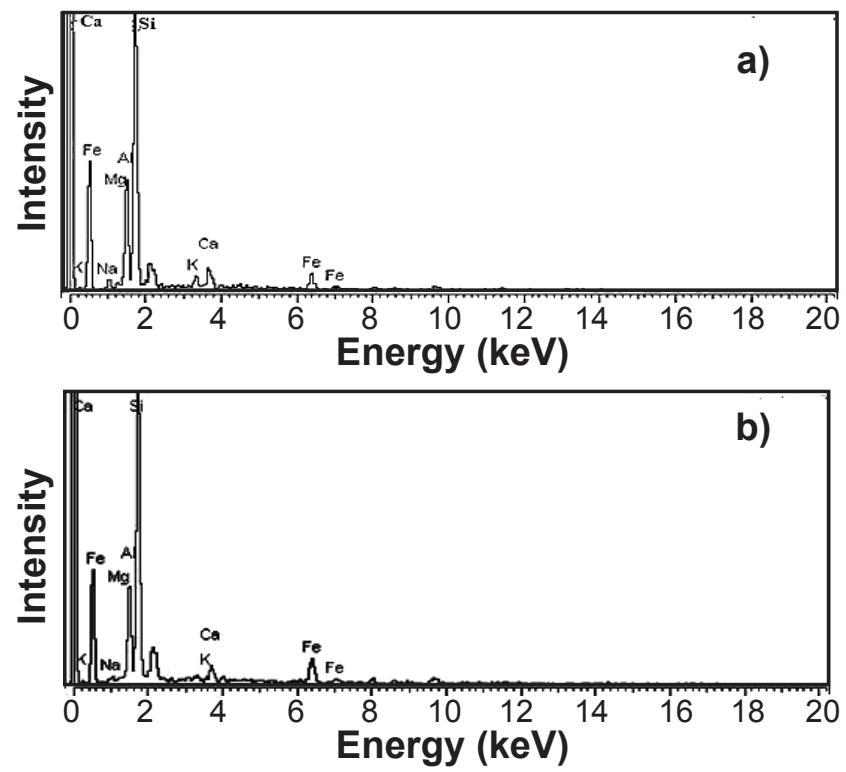

Figure 5: EDS spectra of the selected pottery samples of Porunthal: a) PP1; and b) PP4.

[Figura 5: Espectros de EDS das amostras de cerâmica selecionadas de Porunthal: a) PP1; e b) PP4.] atmosphere in which the clay was fired [35]. Russell [36] and Yariv and Mendelovici [37] discussed that the pattern was the initial vitrification stage of the non-calcareous clay, which may have been fired within the temperature range of 800 to $850{ }^{\circ} \mathrm{C}$ in an oxidizing atmosphere. The sample PP1 was in the initial vitrification degree and product of a non-calcareous clay. So, the sample may have been fired in the oxidizing atmosphere within the range of 800 to $850{ }^{\circ} \mathrm{C}$. When non-calcareous clays are fired in a reducing atmospheric condition, it provides the development of a distinctive behavior with the release of gas after the starting of vitrification. The SEM images of the pottery shreds showed the presence of some slight buckling and rounding of the edges of the clay plates, and indicated that it could be an earlier stage in the development of a vitrification degree; such kind of stage is also known as no vitrification (NV) stage. The non-calcareous clay fired at a temperature of less than $750{ }^{\circ} \mathrm{C}$ produces no vitrification [38]. SEM image of sample PP4 (Fig. 6b) showed no vitrification (NV). The archaeology sample PP4 was of the non-calcareous type of clay fired in the reducing atmosphere and was subjected to a firing temperature below $750{ }^{\circ} \mathrm{C}$ during the production of potteries. The results of SEM-EDS were also confirmed by FTIR, XRD, and thermal (TGA/DTG) analyses.
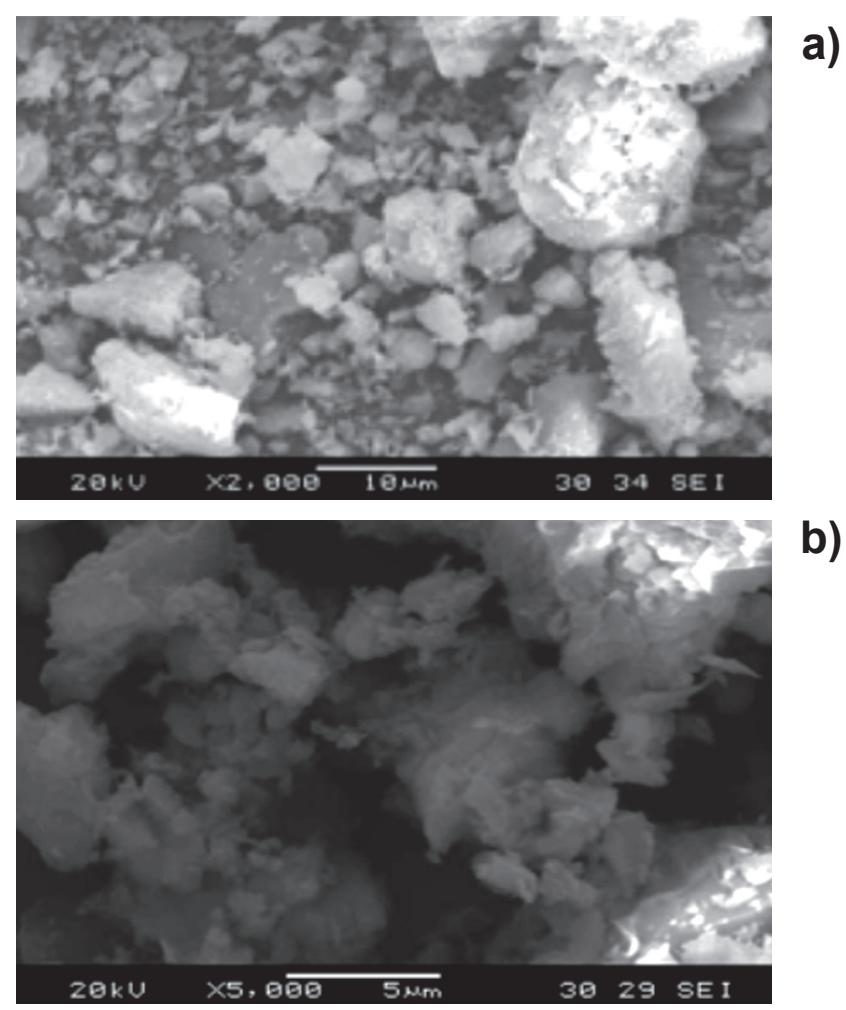

b)

Figure 6: SEM micrographs of the pottery samples: a) PP1; and b) PP4.

[Figura 6: Micrografias de MEV das amostras de cerâmica: a) PP1; e b) PP4.]

\section{CONCLUSIONS}

A combination of analytical techniques such as FTIR, 
XRD, TGA/DTG, and SEM-EDS was used to characterize the different pottery samples excavated from Porunthal, Tamil Nadu, India. FTIR analysis provided a detailed description of the minerals in which the findings showed that the production technology during manufacturing, and the firing temperature was estimated above $650{ }^{\circ} \mathrm{C}$. XRD analysis clearly showed that all investigated archaeological pottery samples were composed of different phases, as indicated in the FTIR study. The results of thermal analysis (TGA/DTG) showed larger weight loss at dehydroxylation than the dehydration and decomposition of organic material used in the manufacturing of pottery; this study also determined the firing temperature. SEM analysis indicated the range of temperature and firing conditions achieved by the artisans at the time of production, and the data obtained by EDS allowed to differentiate the samples into the types by their calcareous or non-calcareous nature, and also to identify the minerals present in it. The results of FTIR analysis coincided well with the analyzes of XRD, TGA-DTG, and SEM-EDS performed on the samples. The results of all the characteristics from spectroscopic techniques confirmed that all the samples were fabricated by the artisans locally with the same raw materials and also which were fired at the same temperature.

\section{REFERENCES}

[1] R.M. Ion, M.L. Ion, R. Fierascu, I. Dumitriu, F. Rugina, S. Cosulet, V.I.R. Niculescu, Bul. Univ. Valahia Targoviste Sec. Ing. Mater. Mecatron. 5 (2007) 62.

[2] R.L. Bishop, R.L. Rands, G.R. Holley, M.B. Schiffer (Ed.), "Adv. archaeol. method theory" 5, Acad. Press, New York (1982) 275.

[3] G.E. De Benedetto, B. Fabbri, S. Gualtieri, L. Sabbatini, P.G. Zambonin, J. Cult. Herit. 6 (2005) 205.

[4] G. Raja Annamalai, R. Ravisankar, A. Rajalakshmi, A. Chandrasekaran, K. Rajan, Spectrochim. Acta A 133 (2014) 112.

[5] G. Raja Annamalai, R. Ravisankar, A. Naseerutheen, A. Chandrasekaran, K. Rajan, Optik 125 (2014) 6375.

[6] R. Ravisankar, G. Raja Annamalai, A. Naseerutheen, A. Chandrasekaran, M.V.R. Prasad, K.K. Satpathy, C. Maheswaran, Spectrochim. Acta A 115 (2013) 845.

[7] R. Ravisankar, A. Naseerutheen, G. Raja Annamalai, A. Chandrasekaran, A. Rajalakshmi, K.V. Kanagasabapathy, M.V.R. Prasad, K.K. Satpathy, Spectrochim. Acta A 121 (2014) 457.

[8] L. Maritan, L. Nodari, C. Mazzoli, A. Milano, U. Russo, Appl. Clay Sci. 31 (2006) 1.

[9] G. Clark, B.F. Leach, S. O'Conner (Ed.), "Islands of inquiry: colonization, seafaring and the archeology of maritime landscape papers in honor of Atholl Anderson", Austral. Nat. Univ. Press (2008) 435.

[10] V.A. Drebushchak, L.N. Mylnikova, T.N. Drebushchak, V.V. Boldyrev, J. Therm. Anal. Calorim. 82 (2005) 617.

[11] Y. Maniatis, A. Simopoulos, A. Kostikas, J. Am. Ceram. Soc. 64 (1981) 263.
[12] K. James Feathers, J. Archaeol. Method Theory 13, 2 (2006) 89.

[13] G.E. De Benedetto, R. Laviano, L. Sabbatini, P.G. Zambonin, J. Cult. Herit. 3 (2002) 177.

[14] D. Barilaro, G. Barone, V. Crupi, M.G. Donato, D. Majolino, G. Messina, R. Ponterio, J. Mol. Struct. 744-747 (2005) 827.

[15] R. Ravisankar, G. Raja Annamalai, K. Rajan, A. Naseerutheen, G. Senthilkumar, Int. J. Sci. Innov. Discov. 2, 1 (2012) 53.

[16] G. Raja Annamalai, G. Senthilkumar, J. Kores, R. Ravisankar, BAOJ Physics 3, 4 (2017) 1.

[17] F.D. Elsass, D. Oliver, Clay Miner. 13 (1978) 299.

[18] G. Kurap, S. Akyuz, T. Akyuz, S. Basaran, B. Cakan, J. Mol. Struct. 976 (2010) 161.

[19] P. Mirti, A. Perardi, M. Gulmini, Archaeometry 48 (2006) 31.

[20] S.N. Ghosh, J. Mater. Sci. 13 (1978) 1877.

[21] M. Sendova, V. Zhelyaskov, M. Scalera, M. Ramsey, J. Raman Spectrosc. 36 (2005) 829.

[22] M. Bouchard, D.C. Smith, Spectrochim. Acta A 59 (2003) 2247.

[23] R. Martineau, P. Pétrequin, in: Arts du feu et productions artisanales, $\mathrm{XX}^{\mathrm{èmes}}$ Renc. Int. Archéol. Hist. Antibes, APDCA, Antibes (2000) 337.

[24] K. Ramasamy, M. Kamalakannan, Indian J. Pure Appl. Phys. 25 (1987) 284.

[25] Mineral powder diffraction file, Joint Committee on Powder Diffraction Standards (2003).

[26] G. Brone, V. Crupi, S. Galli, D. Majolino, P. Migliardo, V. Venruti, J. Mol. Struct. 651-653 (2003) 449.

[27] F. Mazzi, G.P. Bernardini, A. Carobbi, "Mineralogia speciale" II, USES Ed. Sci., Firenze (1983).

[28] M. Maggetti, in: Archaeol. ceram., J.S. Olin, A.D. Franklin (Ed.), Smithsonian Inst. Press (1982) 121.

[29] M. Maggetti, Br. Mus. Occas. Pap. 19 (1981) 33.

[30] R. Ravisankar, A. Naseerutheen, A. Rajalakshmi, G. Raja Annamalai, A. Chandrasekaran, Spectrochim. Acta A 129 (2014) 201.

[31] V.A. Drebushchak, L.A. Mylnikova, T.N. Drebushchak, J. Therm. Anal. Calorim. 104 (2011) 459.

[32] A. Moropoulou, A. Bakolas, K. Bisbikou, Thermochim. Acta 2570 (1995) 743.

[33] R. Padilla, O. Schalm, K. Janssens, R. Arrazcaeta, P. Van Espen, Anal. Chim. Acta 535 (2005) 201.

[34] Y. Maniatis, M.S. Tite, J. Archaeol. Sci. 8 (1981) 59.

[35] G. Velraj, K. Janaki, A. Mohammed Mustafa, R. Palanivel, Appl. Clay Sci. 43 (2009) 303.

[36] J.D. Russell, in: Handb. determ. methods clay mineral., M.J. Wilson (Ed.), Chapman Hall, New York (1987) 133.

[37] S.H. Yariv, E. Mendelovici, Appl. Spectrosc. 33, 4 (1979) 410.

[38] G. Velraj, R. Ramya, Hemamalini, J. Mol. Struct. 1028 (2012) 16.

(Rec. 14/06/2019, Rev. 21/11/2019, 25/12/2019, 01/02/2020, Ac. 05/02/2020) 